\title{
EXOGENOUS FORCES IN THE DEVELOPMENT OF OUR BANKING SYSTEM
}

\author{
George W. Mitchell*
}

Some firms and industries have created a product or service, built up public awareness and acceptance for it, and, using generative, adaptive, and innovative forces from within, have established a role and importance for their own enterprise. The result is a de novo industrial-commercial business or complex.

Banking is not such an enterprise or industry. It has had a pattern of traditional services, an imposed molecular structure, and a pedestrian operating technology, none of which it could call its own. It has not innovated its service products nor shown much adaptive ingenuity in their promotion. Its favorite image has been a passive conformity to the mores of its better customers. Its competitive aggressiveness has been schizophrenic, with large sectors of the industry advocating or supporting publicly administered price ceilings for time deposits, public prohibitions against the absorption of exchange, and a variety of regulatory devices or postures that by sanction or promise dilute competitive ingenuity.

In some measure this unflattering characterization of banking simply reflects the extraordinary economic vicissitudes experienced by banking institutions in the r93os and in World War II and its aftermath. The Great Depression conditioned bank managements and bank regulators for a long time to a deadening apprehension of future commitments and a dedication to liquidity. World War II inflation and vigorous growth in demand deposits produced banking euphoria by flooding the system with loanable resources and restricting the use of these resources to the alternatives of a wartime economy. Even in the early postwar years, the major challenge of banking management still revolved around managing a portfolio of government securities. These features of the early postwar banking system are evident from the balance sheets of the time.

As late as the end of 1947 , seventy-three per cent of commercial banking's deposit resources was in the form of demand deposits-sixty-five per cent being deposits of individuals, partnerships, and corporations and eight per cent deposits of the federal government, states, and municipal subdivisions. In the \$130 billion aggregate of deposits, time and savings accounts amounted to only $\$ 35$ billion, and passbook savings accounted for over ninety per cent of that figure. In those days the banking system was getting its resources almost effortlessly.

Portfolio and loan totals of the time also reveal the lack of aggressiveness in bank managements. Treasury securities made up sixty per cent of the total of loans and investments, and tax exempts and other securities added another eight per cent. Total

\footnotetext{
- Member, Board of Governors of the Federal Reserve System.
} 
loans amounted to only $\$ 38$ billion out of the $\$ \mathrm{rr}_{4}$ billion of loans and investments. And commercial and industrial loans were nearly fifty per cent of the loan total.

\section{SOME EXTERNAL INFLUENCES}

The banking system has been changing significantly since those early postwar years, but most of the forces making for change have been exogenous; change has been induced by the performance and innovation of nonbank competitors, by the penetration of consumer credit markets by vendors, by the proliferation of financing alternatives for borrowers-both as to instruments and institutions-and indirectly by changes in the U.S. nonfinancial economy and the goals that have been set for it.

Recently, and for the future, two developments have been having important and potentially revolutionary effects on banking. One of these-electronic data processing-is purely technological, while the other-a change in money use-is institutional as well as technological. The effects of both of these developments will be transmitted mainly by altering the manner in which banks obtain resources to loan or invest. The changes being wrought will test the innovative and adaptive powers of the banking system to an extent not yet fully recognized.

\section{A. Money Use}

The change in money use is an evolving trend toward more rapid turnover and a corresponding retardation of growth in demand deposits. Between 1949 and I955, turnover outside of New York City rose about half as rapidly as the Gross National Product, but in the period 1955 -1966 it rose at approximately the same rate. Turnover in New York City, which is at very much higher levels, rose in step with GNP in the earlier period and at double the rate of GNP increase in the second period. In line with these turnover trends, demand deposits grew one-half as rapidly as GNP in the earlier period and only one-third as rapidly from I955 through I966. These postwar trends in demand deposits and turnover are important for banking because over eighty per cent of the nation's money is in the form of demand deposits, and demand deposits make up about fifty per cent of the deposit resources of U.S. commercial banks. As this source of funds continues to decline in relative importance, banks will suffer a corresponding decline in investable resources unless they adopt policies to expand time deposits or borrowing or can reverse the trend toward economization of demand deposits by attaching to them useful secondary characteristics that they do not now have.

\section{B. Automation}

The advent of automation in banking and check transactions is now apparent to everyone. Nearly ninety per cent of the checks being written today are sorted and 
accounted for electronically. The Federal Reserve System has announced that after September $1, x 967$, it will not accept checks or drafts for regular processing unless they are machinable, that is, unless they can be handled by high-speed electronic equipment. Utilizing proven technology, we are moving rapidly toward an entirely different system of money settlement which will make federal funds transfers available for all nonlocal transactions of any significant size.

As these and related developments appear on the horizon, a good many bankers and students of banking are trying to evaluate the impact of electronics and automation on the services and structure of banking. For example, will the economies and convenience of electronic accounting for money settlement be confined to large banks? When tied into bank customers' payroll, billing, and receivables bookkeeping and analysis, will the service package be of such size and dimension that banking will take on a major new function, that of the community's accounts keeper? If banks decide thus to make their institutions local binary factories, will they find such operations so profitable and expansible that their first concern will be that of a bookkeeping service bureau and that banking will become their secondary concern? And does this powerful new service potential offer a route for escaping regulatory confinement on corporate growth? Even now, account-keeping packages are becoming an important feature of the services provided by some banks, and the practice is spreading as rapidly as the needed electronic hardware and software become available.

What are the implications of automation for smaller banks? It seems possible that, with recourse to service bureaus, cooperatives, or correspondent facilities, they will not necessarily be seriously handicapped in competing with institutions that operate on a scale which permits on-premises electronic equipment and processing. There are some psychological, or perhaps fancied, advantages to keeping banking operations "under one roof"-one corporate roof, that is. Control of quality, performance, and confidentiality are often mentioned. These arguments, however, seem a bit artificial, for all sorts of economic services are already being contracted by business to outside experts with an actual gain in quality and performance. A loss in confidentiality appears chimerical too-after all, the computer offers a numbered account to everyone, and while all of the attributes of a Swiss-type numbered account are not legally available, electronic bookkeeping is a large step toward anonymity from what we now have.

Regardless of the size of bank, automation is bringing retail banking-the servicing of medium- and small-sized accounts and loans-into a more profitable focus. In the future, dependence on large personal, government, or corporate customers may very well lessen, and, as it does so, bank asset and liability structures will shift to accommodate a new mix of customers made possible by computer facilities which can profitably process the financial needs and transactions of heretofore marginally-sized bank customers. 


\section{INTERMEDIATION-The RoAd to GROWTH}

A. Nature and Significance

In the broadest sense, modern commercial banking can be described as an industry which gathers up financial resources from the whole community of money owners: businesses, households, and governments, and relends them to an equally broad spectrum of private and public users. Over the years the business of acting as a go-between, or intermediary, for owners and users of money and credit has been built up as a personal or institutional relationship. It has not depended on sophisticated products or processes or on complex machinery.

Attracting demand deposits has been a matter of providing a variety of banking services at convenient locations and, for some customers, the assurance of access to bank credit. Attracting time deposits, the other major source of lending capacity, has involved providing much the same convenience facilities and a somewhat more limited range of services, but these deposits are primarily obtained by the payment of competitive interest rates. The advantages that banks, as well as other intermediaries, offer a large number of investors is a combination of yield, liquidity, and convenience which market instruments, their major competitors, seldom can match. Indeed, several kinds of depositary-type financial institutions-commercial banks, savings and loan associations, mutual savings banks, and credit unions-have become extraordinarily facile at the technique of intermediation, the art of borrowing short and lending long.

Though it looks like alchemy and depends to a degree on financial intuition for its profitable use, the transformation of funds serving real liquidity needs for depositors into long-term loan commitments for borrowers is not only practicable but is also a sound operation. Both experience and statistical analysis show that exposure to the liquidity demands of small and medium-sized depositors is, under most circumstances, modest in proportion and predictable in timing and, therefore, manageable. The stability of these pools of funds in the aggregate is dependable, though to a lesser degree than the stability of demand deposits at commercial banks; commercial banking learned long ago that ordinarily money claims (withdrawals) against demand deposits simply roll around the community from one account to another and that if a bank could attract a balanced panel of depositors from various economic and geographic sectors in its service area it could count on surprising stability in the aggregate of its demand deposits.

As the U.S. financial economy grew in stability and strength after the banking reforms of the 1930s, experience with somewhat less liquid claims-time deposits and share accounts-encouraged intermediaries to work greater and greater trans. formations of liquidity promises and attractive yields into long-term loans against which they extended commitments. Without a doubt this process has made saving 
easier and more profitable, and it has accommodated the interest and convenience of much broader groups of savers and investors. It has had an equally beneficent effect on users of loan funds, who have had the benefit of a more competitive environment and in many cases access to credit resources not heretofore available. Increasingly, intermediation became the best of all possible worlds for everyone-the intermediary, the saver, and the borrower.

\section{B. Recent Changes in Banking's "Raw Materials"}

The growing significance of intermediation to the commercial banking system is revealed in Table $x$, which compares capital accounts and liabilities (excluding interbank) of all insured commercial banks as of the end of 1956 and I966. In 1956, demand deposits comprised 66.2 per cent of the total compared to 45.4 per cent at the end of rg66. Time and savings deposits comprised only 24.5 per cent of the 1956 total, but had grown to 4 I.6 per cent by the close of 1966 . Most of the growth in

\section{TABLE I}

Capital Accounts and Liabilities (Not Including Interbank) of All Insured Commercial Banks in the United States

\begin{tabular}{|c|c|c|c|c|}
\hline \multirow[b]{2}{*}{ Capital Accounts } & \multicolumn{2}{|c|}{ December 1956} & \multicolumn{2}{|c|}{ December 1966} \\
\hline & $\begin{array}{l}\text { \$ Mil. } \\
16,301\end{array}$ & $\begin{array}{l}\% \\
7.6\end{array}$ & $\begin{array}{l}\text { \$ Mil. } \\
31,609\end{array}$ & $\%$ \\
\hline $\begin{array}{l}\text { Borrowings } \\
\text { Federal funds } \\
\text { Other liabilities for borrowed money }\end{array}$ & 74 & 0.0 & $\begin{array}{l}2,824 \\
1,893\end{array}$ & $\begin{array}{l}0.7 \\
0.5\end{array}$ \\
\hline Total & 74 & 0.0 & 4,717 & 1.2 \\
\hline $\begin{array}{l}\text { Demand Deposits } \\
\text { Mutual gavings banks and savings \& loan } \\
\text { Other IPC } \\
\text { U. S. Government } \\
\text { States and political subdivisions } \\
\text { Foreign } \\
\text { Certified \& officers checks }\end{array}$ & $\begin{array}{r}111,048 \\
14,339 \\
10,449 \\
1,794 \\
3,785\end{array}$ & $\begin{array}{r}52.0 \\
6.7 \\
4.9 \\
0.8 \\
1.8\end{array}$ & $\begin{array}{r}3,075 \\
141,620 \\
4,975 \\
14,951 \\
2,653 \\
6,956\end{array}$ & $\begin{array}{r}0.8 \\
36.9 \\
1.3 \\
3.9 \\
0.7 \\
1.8\end{array}$ \\
\hline Total & 141,415 & 66.2 & 174,230 & 45.4 \\
\hline $\begin{array}{l}\text { Time and Savings Deposits } \\
\text { Savings deposits } \\
\text { IPC time deposits } \\
\text { States and political subdivisions } \\
\text { Foreign } \\
\text { Special accounts }\end{array}$ & $\begin{array}{r}48,193 \\
\\
2,384 \\
1,254 \\
235 \\
\end{array}$ & $\begin{array}{r}22.6 \\
1.1 \\
0.7 \\
0.1 \\
\end{array}$ & $\begin{array}{r}89,706 \\
49,986 \\
13,414 \\
4,470 \\
2,226\end{array}$ & $\begin{array}{r}23.3 \\
13.0 \\
3.5 \\
1.2 \\
0.6\end{array}$ \\
\hline Total & 52,066 & 24.5 & 159,802 & 41.6 \\
\hline $\begin{array}{l}\text { Acceptances outstanding } \\
\text { Other liabilities }\end{array}$ & $\begin{array}{r}755 \\
2,813\end{array}$ & $\begin{array}{l}0.4 \\
1.3\end{array}$ & $\begin{array}{r}2,233 \\
11,412\end{array}$ & $\begin{array}{l}0.6 \\
3.0\end{array}$ \\
\hline Total of Capital Accounts and Liabilities & 213,424 & 100.0 & 384,003 & 100.0 \\
\hline
\end{tabular}


the time and savings category occurred in time deposits of individuals, partnerships, and corporations ("IPC").

The extent to which the sources of banking's "raw materials"-deposits, borrowings, and capital-are changing is undoubtedly significant for future developments. Projecting historical trends by reference to existing deposit and debt instruments, however, will not take into account the financial innovations on which banks may become increasingly dependent.

For example, the Federal Reserve System conducted a survey of the ownership of time and savings deposits held by Federal Reserve member banks in June 1957, and again in May rg66. The survey was repeated on January $3^{\mathrm{r}}$ of this year. These data are shown in Table 2 and show the structural changes within the IPC time and savings category. In the 1957 survey there were four categories of time accounts tabulated: the largest-regular savings accounts-was eighty-seven per cent of the total. In the 1967 survey nine categories were tabulated, and, while regular savings accounts was still the largest category, it had shrunk to sixty per cent of the total.

Accelerated growth in time deposits began early in 1957 as a result of increases in deposit interest rates announced by banks late in 1956 . These were in response to an upward revision in the maximum limits on rates which banks were permitted, by

TABLE 2

Types of Time and Savings Deposits of Individuals, Partnerships, and Corporations Held by Member Banks on June 6, 1957, May ix, 1966, and January 31, x967

\begin{tabular}{|c|c|c|c|c|c|c|}
\hline \multirow[b]{2}{*}{ Saving Deposits } & \multicolumn{2}{|c|}{ June 6, $1957^{1}$} & \multicolumn{2}{|c|}{ May $11,1966^{2}$} & \multicolumn{2}{|c|}{ Jan. $31,1067^{2}$} \\
\hline & $\begin{array}{l}\text { \$ Mil. } \\
\mathbf{3 5 , 7 3 7}\end{array}$ & $\begin{array}{c}\% \\
87.4\end{array}$ & $\begin{array}{l}\text { S Mil. } \\
72,871\end{array}$ & $\begin{array}{c}\% \\
65.7\end{array}$ & $\begin{array}{l}\text { S Mil. } \\
70,701\end{array}$ & $\begin{array}{c}\% \\
60.5\end{array}$ \\
\hline $\begin{array}{l}\text { Consumer-type Time Deposits } \\
\text { (less than } \$ 100,000) \\
\text { Savings bonds } \\
\text { Nonnegotiable C/Ds } \\
\text { Negotiable C/Ds } \\
\text { Open account time deposits }\end{array}$ & & & $\begin{array}{r}856 \\
12,363 \\
3,197 \\
1,244\end{array}$ & $\begin{array}{r}0.8 \\
11.1 \\
2.9 \\
1.1\end{array}$ & $\begin{array}{r}1,409 \\
17,435 \\
4,381 \\
1,856\end{array}$ & $\begin{array}{r}1.2 \\
14.0 \\
3.7 \\
1.6\end{array}$ \\
\hline Total & & & 17,660 & 15.9 & 25,081 & 21.4 \\
\hline $\begin{array}{l}\text { Business-type Time Deposits } \\
\text { ( } \$ 100,000 \text { or more) } \\
\text { Negotiable C/Ds } \\
\text { Nonnegotiable C/Ds } \\
\text { Open account time deposits }\end{array}$ & & & $\begin{array}{r}13,815 \\
1,968 \\
975\end{array}$ & $\begin{array}{r}12.4 \\
1.8 \\
0.9\end{array}$ & $\begin{array}{r}13,018 \\
2,814 \\
1,826\end{array}$ & $\begin{array}{r}11.1 \\
2.4 \\
1.6\end{array}$ \\
\hline Total & & & 16,758 & 15.1 & 17,658 & 15.1 \\
\hline $\begin{array}{l}\text { Total C/Ds } \\
\text { Total open time deposits } \\
\text { Christmas saving \& other special } \\
\text { accounts }\end{array}$ & $\begin{array}{r}1,961 \\
2,254 \\
931 \\
\end{array}$ & $\begin{array}{l}4.8 \\
5.5 \\
2.3 \\
\end{array}$ & 3,655 & 3.3 & 3,450 & \\
\hline Total & 40,883 & 100.0 & 110,944 & 100.0 & 116,800 & 2.0 \\
\hline
\end{tabular}

144 Fed. Regerve Bulu. 424 (1958).

253 FED. RESERVE BULL. 518 (1967). 
government regulation, to pay on such deposits, effective January 1957. By June of that year, total time and savings deposits of Federal Reserve member banks had increased to $\$ 44.7$ billion from the $\$ 4$ I.2 billion in June I956. (Demand deposits had increased only $\$ 0.4$ billion during the same year.) Of the $\$ 44.7$ billion total time and savings deposits in June 1957, only \$r.9 billion, or 4.4 per cent, were in certificates of deposit, and most of these (\$r.3 billion) were held in country banks. Certificates of deposit had traditionally been used by country banks in the Midwest, and were more important in Federal Reserve districts such as St. Louis and Minneapolis than in the banking centers of New York and Chicago. There is no breakdown of these certificates according to denomination, but it is safe to assume that almost all of these $\mathrm{C} / \mathrm{D}$ s were under $\$ 100,000$, and were for all practical purposes nonnegotiable. The remaining $\$ 0.6$ billion held by the reserve city banks were divided as to type (the survey at that time gave no exact breakdown), and it can be seen that the large negotiable $\mathrm{C} / \mathrm{D}$ had not yet made an important appearance as a money market instrument.

Table 2 also shows that by May $x \mathrm{I}, \mathrm{x} g 66$, nonnegotiable C/Ds of under \$roo,000 had grown to over \$12 billion. These are in the category that are regarded as "consumer-type" time deposits. The "business-type" time deposits (\$100,000 or more and negotiable) had grown to over $\$ 3$ billion. The importance of this instrument is underestimated in the table because only the IPC component is shown. An additional $\$ 5$ billion of such instruments is held by state governments, foreign holders, and others. The table shows that consumer-type $\mathrm{C} / \mathrm{Ds}$ have continued to increase to an important extent since May 1966.

TABLE 3

Share of Funds Sutplied

(In per cent)

\begin{tabular}{|c|c|c|c|}
\hline & $\begin{array}{c}\text { Commercial } \\
\text { Banks }\end{array}$ & $\begin{array}{c}\text { Nonbank } \\
\text { Financial } \\
\text { Institutions }\end{array}$ & $\begin{array}{c}\text { Nonfinancial } \\
\text { Public }\end{array}$ \\
\hline 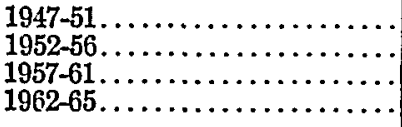 & $\begin{array}{l}18.9 \\
23.1 \\
24.7 \\
35.1\end{array}$ & $\begin{array}{l}41.8 \\
49.8 \\
47.6 \\
42.8\end{array}$ & $\begin{array}{l}26.7 \\
20.4 \\
16.5 \\
10.6\end{array}$ \\
\hline
\end{tabular}

Note: The components do not add up to 100 per cent because the government and foreign sectors are not included.

Throughout the postwar period, banking's role as a supplier of funds to the economy has grown steadily, as Table 3 discloses. In the first five postwar years banks supplied less than twenty per cent of total funds raised; but by $1962-1965$ the share had risen to about thirty-five per cent. Most of this gain was paralleled by a decline in the proportion of funds raised through the sale of market securities directly to the nonfinancial public, but the market share of nonbank financial intermediaries also declined somewhat from a peak of about fifty per cent reached in the years $1952-1956$. Market shares for the year 1966 were temporarily distorted 
by monetary restraint which impaired the capacity of both bank and nonbank intermediaries to attract funds in competition with security markets.

\section{Intermediation in International Financial Markets}

In recent years U.S. commercial banks have extended their intermediation to international financial markets, again primarily because of exogenous factors. First, the evolution of the U.S. dollar as a vehicle currency in international transactions and as a reserve asset enhanced the importance of New York as an international financial center and led to the development of the so-called "Eurodollar" market in Europe. A recent estimate by the Bank for International Settlements puts the volume of this market at about \$r3 billion.

Second, the formation of the European Economic Community, with its greatly expanded market and its vigorous rate of economic growth, provided incentives for U.S. business to expand in this area, and for U.S. banks to increase their activity in order to meet these new requirements of their regular customers. But U.S. banks have been expanding elsewhere also.

One way of measuring the increasing importance of the international money market as a source of funds to banks is to look at the rates of growth in their short-term liabilities to foreigners. In the five years between the end of r957 and the end of $x$ 662, short-term liabilities to foreign banks (including foreign branches of U.S. banks) and other foreigners expanded at an annual average rate of about $\$ 45^{\circ}$ million. Between 1962 and the end of 1966 , the average annual increment was about \$r.4 billion, even without counting negotiable certificates of deposit. While we do not have separate figures for them, we assume that negotiable C/Ds held by foreigners also increased significantly in the latter period.

In part, this growth in banks' short-term liabilities to foreigners is the counterpart of increasing bank claims on foreigners, which went up by an average of about $\$ 1.2$ billion a year in the period $1960-\mathrm{rg} 63$ and by a record $\$ 2.5$ billion in 1964 following the imposition of the interest equalization tax on foreign security issues. It was this last development, by the way, which did much to lead to the extension of the interest equalization tax to long-term bank loans and the announcement of the voluntary foreign credit restraint program in February 1965. But to a great extent the increase in deposit liabilities reflects the ability of American banks to tap this source of funds.

Operations of foreign branches of U.S. banks have been very important in acquiring these funds. The number of these branches has increased from II 7 at the end of 1955 to 244 at the end of 1966 ; during the same period total assets of the branches have increased by over six times-from $\$ 2$ billion to $\$ 12.4$ billion. A large part of this increase has been in the dollar, or "international," business of the branches as distinguished from transactions in other currencies, their "domestic" business.

A dramatic example of the ability of the branches to acquire funds occurred 
during the scramble for liquidity in the latter part of $I 966$. During this period the branches passed on to their head offices for use in the U.S. market about $\$ 2.5$ billion in funds acquired from foreign holders of dollar balances, including other foreign banks. It is quite clear that from now on the international market will have to be regarded as an important source of funds which American banks may tap when they find it attractive.

III

\section{Banking Structure: Do Compettuive Restraints Impede Bank Response to Market Opportunities?}

\section{A. Constraints of Regulation}

The structure of banking in the United States is generally thought to reflect in a rather large way the constraints of state laws with respect to banking operations. These restrictions impair the freedom of banks to move from their original location, to branch, to merge, or to exploit opportunities outside of their immediate demand deposit service areas. The presumption of statutory containment, however, is often carried too far. It fails to hold up as a complete explanation for the banking system's slowness to develop and respond to market opportunities.

Banks are multiproduct or multiservice firms, and there are many markets in which they are able to participate without significant statutory constrictions. A good example is in their asset acquisitions, where they can compete freely on a nationwide basis with the other banks, other financial institutions, nonfinancial businesses, and individuals for Government securities, corporate securities, state and local securities, mortgages and consumer paper (to some degree), and for business loans of the larger and more important corporations. In these markets, Pacific Coast banks compete with New York, Boston, Chicago, Philadelphia, or Dallas institutions. The ability of banks to make loans and investments and, to a lesser degree, to attract deposits from far beyond their home office locations has served to relax significantly the performance constraints of state laws restricting bank location. But despite the fact that banking in the United States as a whole has been able to respond reasonably well to many needs of our over-all economic system and to business practices and consumer habits, there is no gainsaying that in some economic and geographic sectors the efficiency and services of banking have been circumscribed by regulatory policies and the confinement of state laws and conforming federal practices.

\section{B. Structural Constraints}

\section{Describing Banking Structure}

The term "banking structure" is used frequently and easily without specification as to its precise meaning, but generally the reference is to number, size, and location of banks. Thus, there were, at the end of $x g 66,13,770$ commercial banks operating out 
of 30,000 offices with $\$ 330$ billion in deposits (excluding deposits of other commercial banks). On the average, there was an office for every 6,700 persons, but in actual fact a large number of the 30,000 offices were in relatively small communities, and in these locations they ordinarily served populations of less than 1,500. In the nation, outside of metropolitan areas, there were 7,600 one-office towns, and nearly all of these were the sole office of an independent bank. There were 1,600 communities with two offices and goo with three or more. All of the other banking offices were in metropolitan areas.

While such demographic data are useful in understanding the functioning of our banking system, the concept of "banking structure" should be expanded to consider the degree and nature of a bank's participation in various asset or deposit markets. Banks of similar size and location do not necessarily evidence similar operating policies or have similar operating opportunities-but the structure of their assets and liabilities ordinarily reveals the determining influence of various environmental conditions.

Moreover, when we refer to a bank in the United States it may be to an institution with a few million dollars of deposits oriented to the needs and outlook of sparsely populated farming areas, or it may be a multioffice and multibillion dollar institution serving the population of an entire metropolitan area or state, and experiencing rapid economic growth.

The large banks are growth- as well as profit-minded. They cultivate customers on a nationwide, if not a worldwide, scale, even though their local base of operations may be eroded by confining legislation and economic stagnation. On the other hand, the small community banks are locally oriented and resigned to accepting the community's economic growth and development as a limiting factor in their growth goal.

The problem of characterizing banking structure by size, location, and concentration involves criteria for size and a method of determining significant market areas. Bank size can be defined, for example, in terms of total resources, or total deposits, or demand deposits, or demand deposits of individuals, partnerships, and corporations, or demand deposits IPC under $\$ 100,000$, or demand deposits IPC under $\$ 25,000$ or $\$ 10,000$. These are alternative measures; some are better than others, given a particular purpose. Total deposits is probably the best measure of size despite its shortcomings as an indication of local activity-a shortcoming that arises from the fact that it includes both local and nonlocal deposits, for, as is well known, many banks have deposits from firms and individuals far removed from their home office, sometimes as far removed as a distant state or nation.

For a measure of size in a local market, helpful proxies are available in the number of demand deposit accounts or the amount of demand deposits in accounts with balances of less than $\$ 100,000$ or even $\$ 25,000$. The logic of the proxies using size-ofaccount data is that, while there is no sure way of knowing how many deposit accounts over $\$ 100,000$ are nonlocal, it is fairly sure that many of them are of this character. 
And as to the accounts under $\$ 25,000$, we can be quite sure that most of these deposits are of a strictly local character-owned by local individuals, businesses, or corporations. This fact makes the size group of under $\$ 25,000$ a reasonable proxy for bank participation in the local deposit and credit markets.

\section{Measuring Banking Concentration}

A major source of interest in banking structure arises from its impact on banking competition. The geographical areas that encompass important banking markets may be local, regional, or national. The local markets are usually a metropolitan area, a city, a county or town, or even a neighborhood. The regional markets can be approximated by regarding a state or group of states as a significant area. The advantage of regarding a state as a market area is that more pertinent economic and demographic data are available for states. Moreover, aggregate state data can be viewed as an average structure, reflecting both the over-all economic environment of the state and the statutory freedom or constraint imposed by the state's banking laws.

For any given geographical area and size criterion, there are data and a technique for summarizing structural characteristics. From periodic (approximately quarterly) call reports for all insured banks in the United States, a uniform balance sheet and supplemental exhibits detail a variety of asset and liability items by bank. These data can be tabulated for any classification or array of banks by any asset or liability category on the call.

For example, using the entire United States as the geographical area and total deposits as a measure of size, we derive the following table on banking concentration (as of December 1965 ):

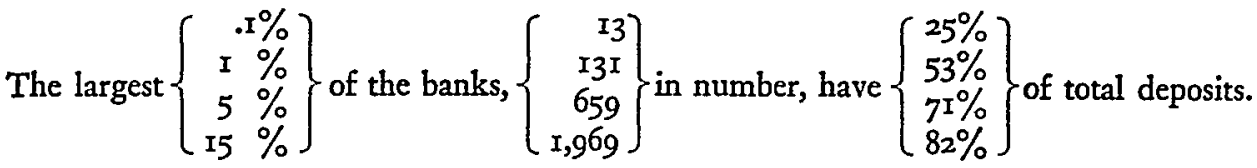

Looking at the other end of the spectrum:

The smallest $\left\{\begin{array}{l}25 \% \\ 50 \% \\ 75 \% \\ 85 \%\end{array}\right\}$ of the banks, $\left\{\begin{array}{r}3,283 \\ 6,585 \\ 9,847 \\ 11,160\end{array}\right\}$ in number, have $\left\{\begin{array}{r}1.6 \% \\ 5.1 \% \\ 12.2 \% \\ 17.5 \%\end{array}\right\}$ of total deposits.

These concentration characteristics for the nation are also rather surprisingly typical for a large number of individual states with a variety of banking structures. For example, states where as much as fifty per cent of the deposits are held in one per cent of the banks are as diversified in banking structure as California (statewide branching), Georgia (limited branching and holding company), Illinois (unit only), Minnesota (unit and holding company), and New York (limited branching and holding company). In these states and in several other groups of states, dissimilar banking laws 
have led to some obvious differences in structure, but the concentration figures are very much alike. On the other hand, there are instances, particularly in the South and Southeast, where branching restrictions, or their absence, seem to have had a marked effect on concentration. The Carolinas and Virginia, for example, show the effects on concentration of branching freedom, just as Arkansas, Mississippi, and West Virginia show the results of branching restraints.

Without doubt the variegation in state banking structures is greater because of the differences in regulatory constraints, but state-to-state differences in economic environment are often an overriding factor tending to accentuate or moderate those constraints. And the response of bankers themselves to the combination of the economic and regulatory environment is still another significant factor affecting the banking structures actually existing.

\section{ConCLUSION}

Whatever phase of commercial banking one examines, the imprints of environment, precedent, and authority are evident. In the beginning "bankers' money"demand deposits or notes-was an adaptation of the "sovereign's money"-coin and currency-with the identical problem of confidence and a similar opportunity for gain. In our time, the development of new lending techniques and instruments, the introduction of credit to new users and uses, and the competitive tapping of loanable resources are, by and large, innovations taken over by the banking system after experimental and developmental costs have been charged off by someone else. Banking has not done badly, profitwise, in its imitative, cautious role, but it may not-up to now-aspire to the reputation of a growth industry. However, the impact of automation and changing money use on banking is potentially capable of transforming the industry into an innovator for the first time in its existence. 